\title{
Response Surface Methodology for Boron Removal by Donnan Dialysis: Doehlert Experimental Design
}

\author{
Ikhlass Marzouk Trifi ${ }^{1}{ }^{\mathbb{D}}$, Lobna Chaabane ${ }^{2}$, Lasâad Dammak ${ }^{2, *}$, Lassaad Baklouti $^{3}$ and Béchir Hamrouni ${ }^{1}$ \\ 1 Laboratoire de Recherche Dessalement et Traitement des Eaux, Faculté des Sciences de Tunis, Université de \\ Tunis El Manar, Tunis 1068, Tunisia; ikhlassmarzouk@gmail.com (I.M.T.); bechir.hamrouni@fst.utm.tn (B.H.) \\ 2 Institut de Chimie et des Matériaux Paris-Est (ICMPE), Université Paris-Est, UMR 7182, CNRS, 2-8 rue Henri \\ Dunant, 94320 Thiais, France; lobna.dammak@u-pec.fr \\ 3 Department of Chemistry, College of Sciences and Arts at Al Rass, Qassim University, Ar Rass 51921, \\ Saudi Arabia; bakloutilassaad@yahoo.fr \\ * Correspondence: dammak@u-pec.fr
}

Citation: Trifi, I.M.; Chaabane, L.;

Dammak, L.; Baklouti, L.; Hamrouni,

B. Response Surface Methodology for Boron Removal by Donnan Dialysis: Doehlert Experimental Design.

Membranes 2021, 11, 731. https://

doi.org/10.3390/membranes11100731

Academic Editor: Jin-Soo Park

Received: 25 August 2021

Accepted: 21 September 2021

Published: 25 September 2021

Publisher's Note: MDPI stays neutral with regard to jurisdictional claims in published maps and institutional affiliations.

Copyright: (c) 2021 by the authors. Licensee MDPI, Basel, Switzerland. This article is an open access article distributed under the terms and conditions of the Creative Commons Attribution (CC BY) license (https:// creativecommons.org/licenses/by/ $4.0 /)$.

\begin{abstract}
The removal of boron by Donnan dialysis from aqueous solutions has been studied according to response surface methodology (RSM). First, a preliminary study was performed with two membranes (AFN and ACS) in order to determine the experimental field based on different parameters, such as the $\mathrm{pH}$ of the feed compartment, the concentration of counter-ions in the receiver compartment, and the concentration of boron in the feed compartment. The best removal rate of boron was $75 \%$ with the AFN membrane, but only $48 \%$ with the ACS membrane. Then, a full-factor design was developed to determine the influence of these parameters and their interactions on the removal of boron by Donnan dialysis. The $\mathrm{pH}$ of the feed compartment was found to be the most important parameter. The RSM was applied according to the Doehlert model to determine the optimum conditions $\left([\mathrm{B}]=66 \mathrm{mg} / \mathrm{L}, \mathrm{pH}=11.6\right.$ and $\left[\mathrm{Cl}^{-}\right]=0.5 \mathrm{~mol} / \mathrm{L}$ ) leading to $88.8 \%$ of boron removal with an AFN membrane. The use of the RSM can be considered a good solution to determine the optimum condition for $13.8 \%$ compared to the traditional "one-at-a-time" method.
\end{abstract}

Keywords: boron; Doehlert design; Donnan dialysis; optimization; response surface methodology

\section{Introduction}

Water present in nature may often neither be used for human consumption nor for industry use, because it may contain relatively high concentrations of various chemical compounds such as boron. There is a small range between boron deficiency and boron toxicity in vegetable crops and other plants [1]. Boron is an essential nutrient for plants; a very low boron content is required in irrigation water for certain metabolic activities, but an increased boron concentration to $4 \mathrm{mg} / \mathrm{L}$ [1] leads to poisoning, reflected by yellowish spots on leaves and fruits, and accelerates decomposition and kills the plants [2]. In drinking water, high boron concentrations can be also toxic to humans. The WHO indicate that the concentration of boron in drinking water should be less than $0.3 \mathrm{mg} / \mathrm{L} \mathrm{[3].}$ The boron concentration is around $5 \mathrm{mg} / \mathrm{L}$ in seawater [4]. The growth in knowledge of the science of boron in recent years has been of great commercial and environmental importance because the element is used in a wide range of industrial applications such as in insulation and textile-grade fiber, borosilicate glass, fire retardants, enamels, glazes and agriculture. The presence of boron in water originates from different sources, such as mineralization. In urban wastewater systems, boron is mainly found in the form of boric acid or borates. Boron removal has been investigated using adsorption [5,6], electrocoagulation $[7,8]$, electrodialysis $[9,10]$, reverse osmosis [11,12], nanofiltration $[13,14]$, microfiltration [15], ion-exchange [15,16], membrane distillation [17] and Donnan dialysis $[18,19]$. In order to choose the simplest and continuous method, Donnan dialysis was conducted in this study. This process is easy to handle and only requires a few chemicals 
and low pumping energy. Donnan dialysis is widely used to recover or concentrate [20-22] and eliminate various ions such as nitrates [23], nitrates and nitrites simultaneously [24], fluorides [25-27], chromium [28,29], phosphates [30] and boron [18,19].

Herein, the removal of boron by Donnan dialysis was investigated using a response surface methodology (RSM) approach. RSM is a collection of mathematical and statistical techniques based on the fit of a polynomial equation to the experimental data, which must describe the behavior of a dataset with the objective of making statistical previsions. The advantage of the RSM approach for optimization is the simultaneous variation of all factors at once in each experiment, the decrease in the number of attempts, the study of a large number of factors, the detection of interactions between factors and obtaining the best possible precision [31]. RSM via the Doehlert design was employed in this study. This design offers many advantages over other designs such as central composite design or Box-Behnken design. Doehlert designs involve a reduced number of experiments. All variables have different numbers of levels, which allows flexibility to assign a large or a small number of levels to the selected variables. In order to obtain maximum information of the system, it is preferable to choose the variable with the stronger effect as the variable with maximum levels. Finally, considering that the efficiency of any experimental design is defined as the number of coefficients of the model divided by the number of experiments, Doehlert design is more efficient than central composite design or Box-Behnken design [24].

In this study, first, the removal of boron was performed with four parameters: counter-ion concentration in the receiver compartment, boron concentration, the $\mathrm{pH}$ in the feed compartment, and anionic exchange membrane type. Secondly, a full factorial design was utilized to study the parameter effects and their interactions. Finally, response surface methodology using Doehlert design was investigated to optimize the Donnan dialysis process.

\section{Experimental}

\subsection{Membranes}

Two membranes were used in the Donnan dialysis process, which were Neosepta ${ }^{\circledR}$ AFN and Neosepta ${ }^{\circledR}$ ACS (supplied by Alstom, Saint-Ouen, France). Their properties were determined according to a French standard NF X 45-200 [32] and are listed in Table 1. The ion-exchange capacity (in meq. of functional sites per gram of dry membrane or per $\mathrm{cm}^{3}$ of wet membrane) was determined following the French standard NF X 45-200 [32].

Table 1. Properties of the anion-exchange membrane used for the boron removal.

\begin{tabular}{cccc}
\hline Membranes & Ion-Exchange Capacity (meq/g) & Water Content $(\%)$ & Thickness $(\boldsymbol{\mu m})$ \\
\hline Neosepta ${ }^{\circledR}$ ACS & 1.85 & 18.9 & 150 \\
\hline Neosepta ${ }^{\circledR}$ AFN & 3.00 & 47.8 & 120 \\
\hline
\end{tabular}

The water content was determinate with a Mettler-Toledo moisture thermo balance device. The water content was calculated with the following relationship:

$$
\mathrm{WC}(\%)=\frac{W_{\mathrm{h}}-\mathrm{W}_{\mathrm{d}}}{\mathrm{W}_{\mathrm{h}}} \times 100
$$

where $\mathrm{WC} \%$ is the water content percentage, $W_{h}$ is the hydrated membrane mass, and $W_{d}$ is the dried membrane mass. The water content is the mass difference between the hydrated membrane (immersed in the appropriate stabilization content and pressed slightly in order to remove the excess liquid), and the dried membrane at $140{ }^{\circ} \mathrm{C}$ (until membrane mass stabilization indicated the total removal of water).

The membrane thickness in the dry state corresponded to a mean value of 10 measurements at different locations using a $1 \mu \mathrm{m}$ resolution Käfer Thickness Dial Gauge. 
Conditioning of the samples before any measurement was necessary, essentially to remove impurities coming from the manufacturing process, as well as to stabilize their physical-chemical properties in order to prepare the samples for use in Donnan dialysis. This conditioning performed done according to the French standard NF X 45-200 [32].

\subsection{Donnan Dialysis (DD)}

Donnan dialysis is a membrane separation process in which an exchange of ions having the same electrical charge between two solutions through an ion-exchange membrane takes place [33-35]. The driving force in Donnan dialysis is the chemical potential gradient; there is a stoichiometric exchange of anions through an anionic exchange membrane, and the process ends only when the Donnan equilibrium is reached. Electroneutrality is sustained; therefore, the same amounts of anions should be exchanged from the feed to the receiver compartment, and vice versa [19,36,37].

Figure 1 shows a schematic flow diagram of Donnan dialysis. The feed and receiver tanks Erlenmeyer flask were used to supply the two cell compartments using a controlled peristaltic pump. In the receiver compartment, solutions containing $\mathrm{NaCl}$ were prepared, and in the feed compartment, a solution containing boron was prepared. The membrane was sandwiched between these two compartments, making a seal at the same time. Two membranes, AFN and ACS, were used. Each experiment lasted seven hours. During dialysis operation, different effects were investigated in order to determine the concentrations of boron. The samples were analyzed for boron concentration by reactions with azomethine- $\mathrm{H}$ followed by absorbance measurements at $420 \mathrm{~nm}$ using a UV-visible spectrophotometer [38]. The concentration was linear in the range of $1-4 \mathrm{mg} / \mathrm{L}$. The samples of higher concentration were diluted in order to match the above linearity range.



Figure 1. Schematic flow diagram of a Donnan dialysis system for boron removal (in an alkaline environment).

The removal rate of boron was calculated with Equation (1):

$$
\mathrm{Y}(\%)=\frac{\mathrm{C}_{0}-\mathrm{C}_{\mathrm{e}}}{\mathrm{C}_{0}} \times 100
$$

where $\mathrm{C}_{0}$ is the initial boron concentration $(\mathrm{mg} / \mathrm{L})$, and $\mathrm{C}_{\mathrm{e}}$ is the equilibrium boron concentration $(\mathrm{mg} / \mathrm{L})$.

\subsection{Optimization of the Removal of Boron by Donnan Dialysis}

First, a full factorial design was used in order to determine the most important and influential parameter in the RSM design according to Doehlert matrix. The software used in this study was NemrodW ${ }^{\circledR}$. NemrodW ${ }^{\circledR}$ software was an essential support for the practical implementation of the experimental research methodology (experimental designs). 


\section{Results and Discussion}

\subsection{The Preliminary Study}

\subsubsection{Effect of $\mathrm{pH}$ in the Feed Compartment}

The $\mathrm{pH}$ effect in the feed compartment was determined with different initial $\mathrm{pH}$ values of feed solutions, ranging from 9.5 to 12.5 , with a concentration of counter-ion of $0.1 \mathrm{~mol} / \mathrm{L}$, initial boron concentration of $50 \mathrm{mg} / \mathrm{L}$ and stirring speed of $500 \mathrm{rpm}$. The two membranes, AFN and ACS, were tested for dialysis operations lasting seven hours. At the outlet of the receiver solution, the variations in boron concentrations under different initial $\mathrm{pH}$ values are presented in Figure 2.

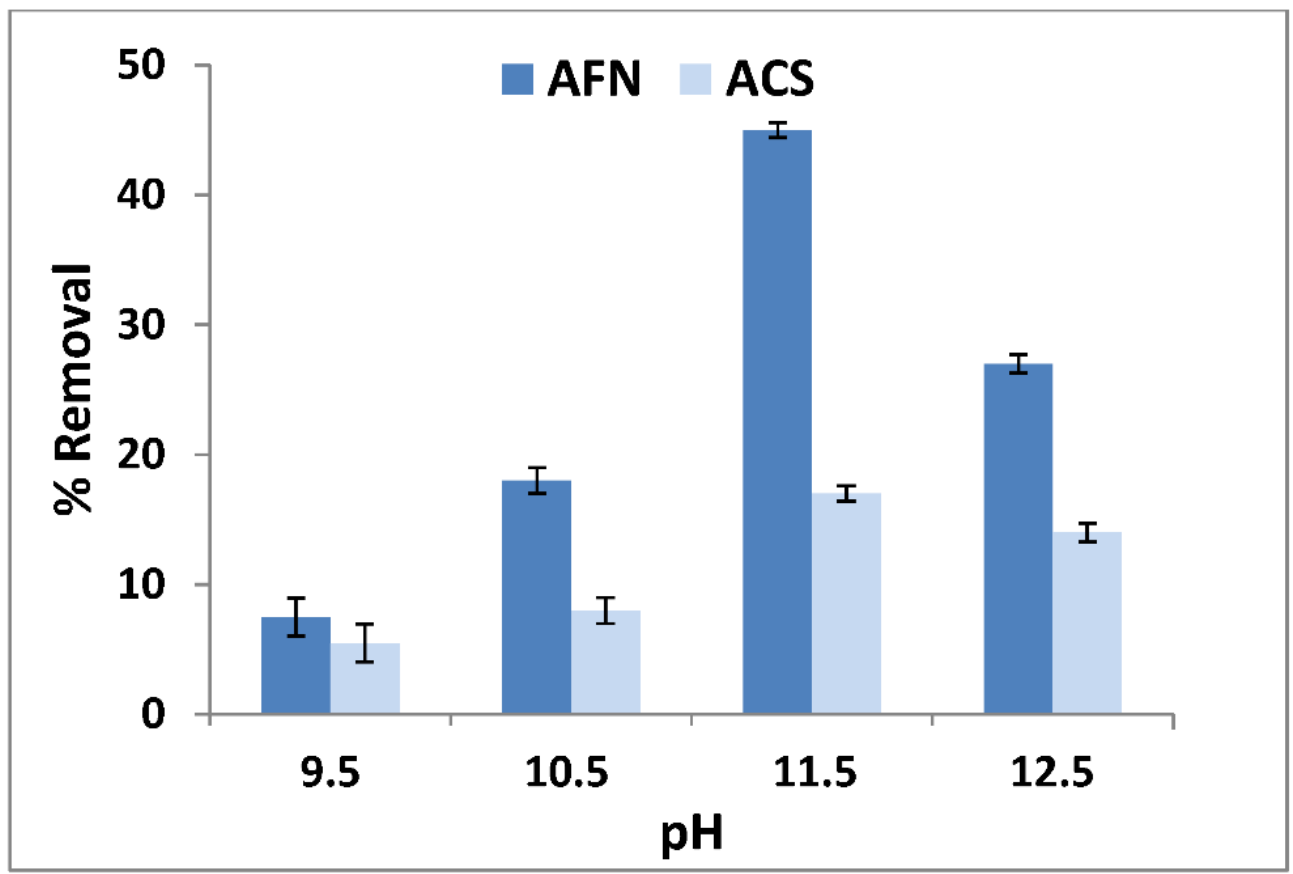

Figure 2. $\mathrm{pH}$ effects on the removal rate of boron.

The effect of $\mathrm{pH}$ was studied first, due to its impact on the transport of boron from the feed compartment to receiver compartment. As shown in Figure 2, the highest removal of boron was obtained at a $\mathrm{pH}$ of 11.5 , with $45 \pm 0.6 \%$ for the AFN membrane and $17 \pm 0.6 \%$ for the ACS membrane. This can be explained by the two existing forms of boron species in aqueous solution under different $\mathrm{pH}$ values, which were boric acid $\mathrm{B}(\mathrm{OH})_{3}$ in dilute aqueous solution below $\mathrm{pH} 7$, and above $\mathrm{pH} 10$, the metaborate anion $\mathrm{B}(\mathrm{OH})_{4}^{-}$became the dominant species in solution $[39,40]$. However, above $\mathrm{pH}=11.5$, the transport of boron was probably affected by the presence and competition with $\mathrm{OH}^{-}$, which decreased boron removal because hydroxyl ion transport was preferred, because the mobility of $\mathrm{OH}^{-}$is much higher than that of boron. In fact, the transport of boron is a process which involves three steps: the boron in feed solution is exchanged with ions or ionizable groups in an anion-exchange membrane; boron is transported in a membrane to the side of the receiver solution; and boron is transferred to a receiver solution with counter ions [21,26]. Thus, it may be concluded that the highest boron transport was achieved at $\mathrm{pH}=11.5$ for the two used membranes. 


\subsubsection{Effect of Chloride Concentration in the Receiver Compartment}

The chloride concentration is one of the parameters affecting the removal of boron through the anionic exchange membrane during the Donnan dialysis operation. Variation in the concentration of counter-ion $\mathrm{Cl}^{-}$from $0.001 \mathrm{~mol} / \mathrm{L}$ to $0.5 \mathrm{~mol} / \mathrm{L}$ in the receiver compartment was investigated in order to explain this impact on the transport of boron $(50 \mathrm{mg} / \mathrm{L})$ through the anionic exchange membrane from the feed compartment to the receiver compartment. The effects of chloride concentration in the receiver compartment for the two membranes are presented in Figure 3, with a $\mathrm{pH}$ of 11.5, a boron concentration of $50 \mathrm{mg} / \mathrm{L}$ in the feed compartment, a stirring speed of $500 \mathrm{rpm}$ and a temperature equal to $25^{\circ} \mathrm{C}$.

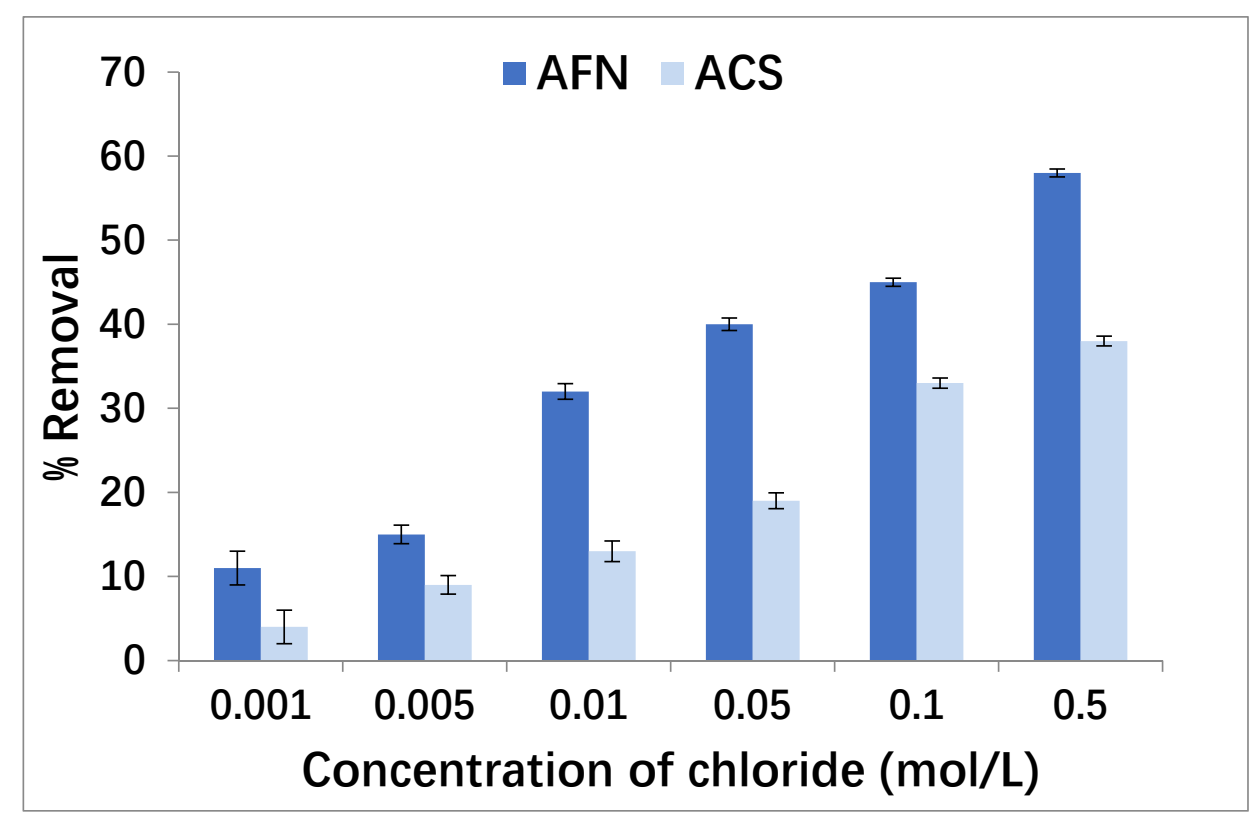

Figure 3. Effect of chloride concentration in the receiver compartment ( $\mathrm{pH} 11.5$, boron concentration $50 \mathrm{mg} / \mathrm{L}$ in the feed compartment, stirring speed of $500 \mathrm{rpm}$ and temperature $25^{\circ} \mathrm{C}$ ).

Figure 3 suggests that the flux of boron ions through anion exchange membranes increases with the increase in chloride concentration from 0.001 to $0.5 \mathrm{~mol} / \mathrm{L}$. The transport

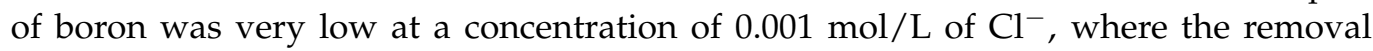
efficiency was $11 \pm 2 \%$ for AFN and $4 \pm 2 \%$ for ACS. However, the removal efficiency improved to $58 \pm 0.47 \%$ for AFN and $38 \pm 0.47 \%$ for ACS at $0.5 \mathrm{~mol} / \mathrm{L}$ of the concentration of $\mathrm{Cl}^{-}$. This is explained by the fact that the concentration gradient of the counter-ions increased; hence, the cross-ion transfer between $\mathrm{Cl}^{-}$and boron improved in order to maintain the electroneutrality. For the two membranes, it seems that the increase in the concentration of counter-ions in the receiver compartment is associated with improvements in boron removal in the feed compartment; this is reflected by improving the kinetics of the exchange. In fact, it is known that ion exchange is faster when the concentration of counter-ions is higher in the receiver compartment [41-43].

\subsubsection{Effect of Boron Concentration in the Feed Compartment}

The boron concentration in feed compartment has an important influence on the removal by Donnan dialysis. Under the conditions of $\mathrm{pH} 11.5$ in the feed compartment, the boron concentration increase from $5 \mathrm{mg} / \mathrm{L}$ to $100 \mathrm{mg} / \mathrm{L}$, and in the receiver compartment, the $\mathrm{Cl}^{-}$concentration is $0.5 \mathrm{~mol} / \mathrm{L}$. The results are presented in Figure 4 . 


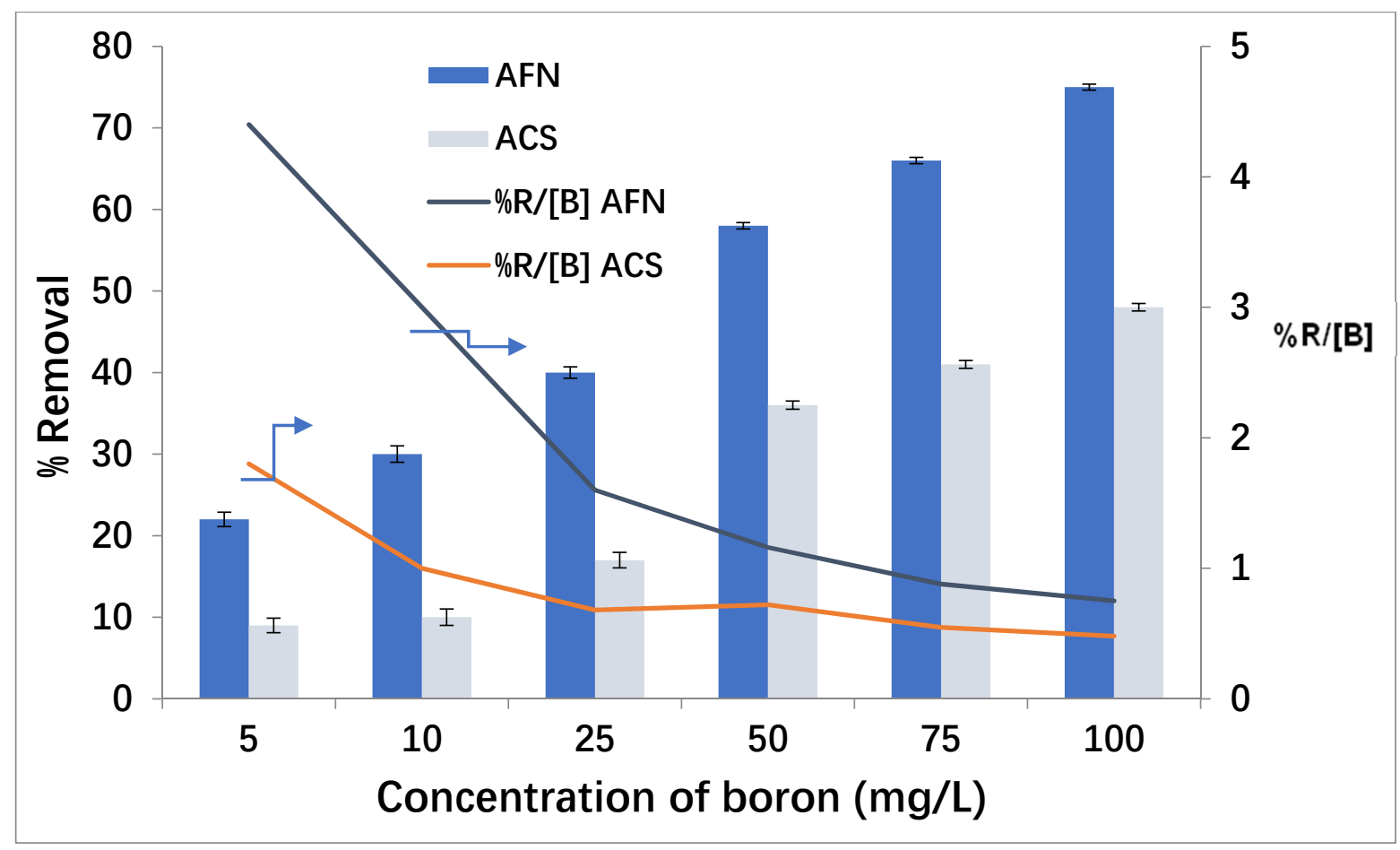

Figure 4. Effect of boron concentration in the feed compartment.

As presented in Figure 4, the increase in initial concentration of boron from $5 \mathrm{mg} / \mathrm{L}$ to $100 \mathrm{mg} / \mathrm{L}$ contributes to maintaining the high concentration gradient of boron, involving an improvement in the cross-ion transfer between $\mathrm{Cl}^{-}$and $\mathrm{B}(\mathrm{OH})_{4}^{-}$. At the lowest concentration of boron in the feed compartment $(5 \mathrm{mg} / \mathrm{L})$, the removal was $22 \pm 1 \%$ for AFN and $9 \pm 1 \%$ for ACS. The increase in boron concentration from $10 \mathrm{mg} / \mathrm{L}$ to $100 \mathrm{mg} / \mathrm{L}$ improved their removal from $30 \pm 1 \%$ to $75 \pm 0.37 \%$ with AFN and from $10 \pm 1 \%$ to $48 \pm 0.5 \%$ with ACS. A similar result was reported by Tor [44].

The $\% \mathrm{R} /[\mathrm{B}]$ ratio, expressed as $\% /(\mathrm{mg} / \mathrm{L})$, indicates the efficiency of boron removal from the feed compartment, in order to explain the diffusion of boron through the membrane. At low concentrations, the diffusion of $B$ through the membrane was performed with the cross-exchange of $\mathrm{Cl}^{-}$. However, in high concentrations (of $\mathrm{B}$ and/or of $\mathrm{Cl}^{-}$), the membrane loses part of its performance (selectivity), and $\mathrm{Cl}^{-}$ions leak without any exchange with boron ions. Therefore, the $\% \mathrm{R} /[\mathrm{B}]$ ratio allows us to conclude that, as the boron concentration in the feed increases, more boron is removed, but in a less efficient manner. As indicated in Figure 4, the \%R/[B] ratio: (i) was always higher for the AFN membrane than for the ACS; and (ii) decreased very rapidly and then tended towards an asymptotic value when the initial feed boron concentration increased. For example, for the AFN membrane, at a boron concentration of $5 \mathrm{mg} / \mathrm{L}$, an efficiency of $4.5 \% /(\mathrm{mg} / \mathrm{L})$ was observed, whereas it was only $0.78 \% /(\mathrm{mg} / \mathrm{L})$ for a concentration of $100 \mathrm{mg} / \mathrm{L}$.

\subsubsection{Membrane Choice}

According to the previous results in Figures 3 and 4, it was observed that the efficiency of boron removal by Donnan dialysis depended significantly on the AEM properties. It is clear to that the AFN membrane had the best removal rate of boron, $75 \pm 1 \%$ in seven hours, compared to the ACS membrane, which had a rate of $48 \pm 0.5 \%$. Thus, AFN is the most efficient membrane. Akretche indicated that (i) a high exchange capacity increases the selectivity between monovalent and multivalent anions because of the higher repulsion charge; (ii) a high thickness decreases the diffusion, giving rise to lower ion flux, and (iii) a high water content can decrease the permselectivity and favors the penetration of bulky ions [45]. In fact, the AFN membrane presents a higher permeability to monovalent than 
bivalent anions with high ion-exchange capacity and the highest water content. On the other hand, the ACS had high thickness and low water content; therefore, it had the lowest permeability. This result is confirmed by the work of Ayyildiz [40], who reported that the removal of boron by Donnan dialysis is more effective with an AFN membrane. Therefore, the AFN membrane was selected for the next study.

\subsection{Full Factorial Design}

The full factorial design $2^{\mathrm{k}}$ was carried out to determine the influence of these factors and their interaction on the removal of boron by Donnan dialysis. The preliminary study (Section 3.1) enabled us to define the experimental field and to determine the level that must take every factor. The three chosen factors were the initial concentration of boron, the concentration of counter-ions, and the $\mathrm{pH}$ of the feed compartment. The choice of limits was fixed in order to better define the studied response (boron removal efficiency). The Donnan dialysis operated with the AFN membrane.

In order to evaluate the influence of operating parameters on the removal of boron by Donnan dialysis, full factorial design was performed. In Table 2, experimental ranges and factors level are presented. In the present study, for the three factor designs mentioned, a full factorial matrix consisting of a set of eight different experiments was used. The experimental response associated with this factorial design is represented by a linear polynomial model, taking into account the interactions between two parameters (second-order model) and neglecting the third-order interactions $\left(\mathrm{X}_{1} \times{ }_{2} \mathrm{X}_{3}\right)$ considered null (Equation (2)):

$$
\mathrm{Y}=\mathrm{b}_{0}+\mathrm{b}_{1} \mathrm{X}_{1}+\mathrm{b}_{2} \mathrm{X}_{2}+\mathrm{b}_{3} \mathrm{X}_{3}+\mathrm{b}_{12} \mathrm{X}_{1} \mathrm{X}_{2}+\mathrm{b}_{13} \mathrm{X}_{1} \mathrm{X}_{3}+\mathrm{b}_{23} \mathrm{X}_{2} \mathrm{X}_{3}
$$

where $Y$ is the experimental response, $X_{i}$ is a coded variable, $b_{i}$ is an estimation of the principal effect of factor $i$ for the response $Y$, and $b_{i j}$ is an estimation of the interaction effect between factor $\mathrm{i}$ and $\mathrm{j}$ for the response $\mathrm{Y}$.

Table 2. Experimental range and factor levels studied in the factorial design.

\begin{tabular}{ccccc}
\hline \multirow{2}{*}{ Factors } & Symbol & $\begin{array}{c}\text { Coded } \\
\text { Symbol }\end{array}$ & & \multicolumn{2}{c}{ Range and Level } \\
\cline { 5 - 6 } & & $\mathrm{X}_{1}$ & 25 & 100 \\
\hline Initial concentration of boron $(\mathrm{mg} / \mathrm{L})$ & {$[\mathrm{B}]$} & $\mathrm{X}_{2}$ & 0.1 & 0.5 \\
\hline Concentration of counter-ions $(\mathrm{mol} / \mathrm{L})$ & {$\left[\mathrm{Cl}^{-}\right]$} & $\mathrm{X}_{3}$ & 10.5 & 12.5 \\
\hline $\mathrm{pH}$ of the solution & $\mathrm{pH}$ & &
\end{tabular}

According to the obtained results in Table 3, the coefficients of the model were calculated, and it was found that (Equation (3)):

$$
Y(\%)=34.85+2.50 X_{1}+3.75 X_{2}+6.15 X_{3}-0.20 X_{1} X_{2}-0.90 X_{1} X_{3}-1.15 X_{2} X_{3}
$$

The last column of Table 3 represents the absolute relative differences (\%) between the experimental and the calculated values. We note that these differences are very small and do not exceed $1.50 \%$. The different coefficients of the polynomial model (Equation (3); $\left.\mathrm{R}^{2}=0.999\right)$, representing the effects and interactions of the various investigated factors, are shown in Figure 5a. The Pareto analysis (Figure 5b) allowed us to check the weight of different coefficients in the experimental domain investigated [46]. Thus, this analysis was calculated using Equation (4):

$$
P_{i}=\left(\frac{b_{i}^{2}}{\sum b_{i}^{2}}\right)^{2} \times 100
$$


Table 3. Full factorial design matrix.

\begin{tabular}{|c|c|c|c|c|c|c|c|c|c|}
\hline $\mathbf{N}^{\circ}$ & {$\left[\mathrm{Cl}^{-}\right]$} & {$[B]$} & $\mathrm{pH}$ & {$\left[\mathrm{Cl}^{-}\right]$} & {$[B]$} & $\mathrm{pH}$ & $Y_{B}(\%)_{\exp }$ & $\mathrm{Y}_{\mathrm{B}}(\%)_{\mathrm{cal}}$ & Relative Difference (\%) \\
\hline 1 & -1 & -1 & -1 & 0.1 & 25 & 10.5 & 19.9 & 20.2 & 1.50 \\
\hline 2 & +1 & -1 & -1 & 0.5 & 25 & 10.5 & 27.7 & 27.4 & 1.09 \\
\hline 3 & -1 & +1 & -1 & 0.1 & 100 & 10.5 & 30.7 & 30.4 & 0.98 \\
\hline 4 & +1 & +1 & -1 & 0.5 & 100 & 10.5 & 36.5 & 36.8 & 0.82 \\
\hline 5 & -1 & -1 & +1 & 0.1 & 25 & 12.5 & 36.9 & 36.6 & 0.82 \\
\hline 6 & +1 & -1 & +1 & 0.5 & 25 & 12.5 & 39.9 & 40.2 & 0.75 \\
\hline 7 & -1 & +1 & +1 & 0.1 & 100 & 12.5 & 41.9 & 42.2 & 0.71 \\
\hline 8 & +1 & +1 & +1 & 0.5 & 100 & 12.5 & 45.3 & 45.0 & 0.66 \\
\hline
\end{tabular}
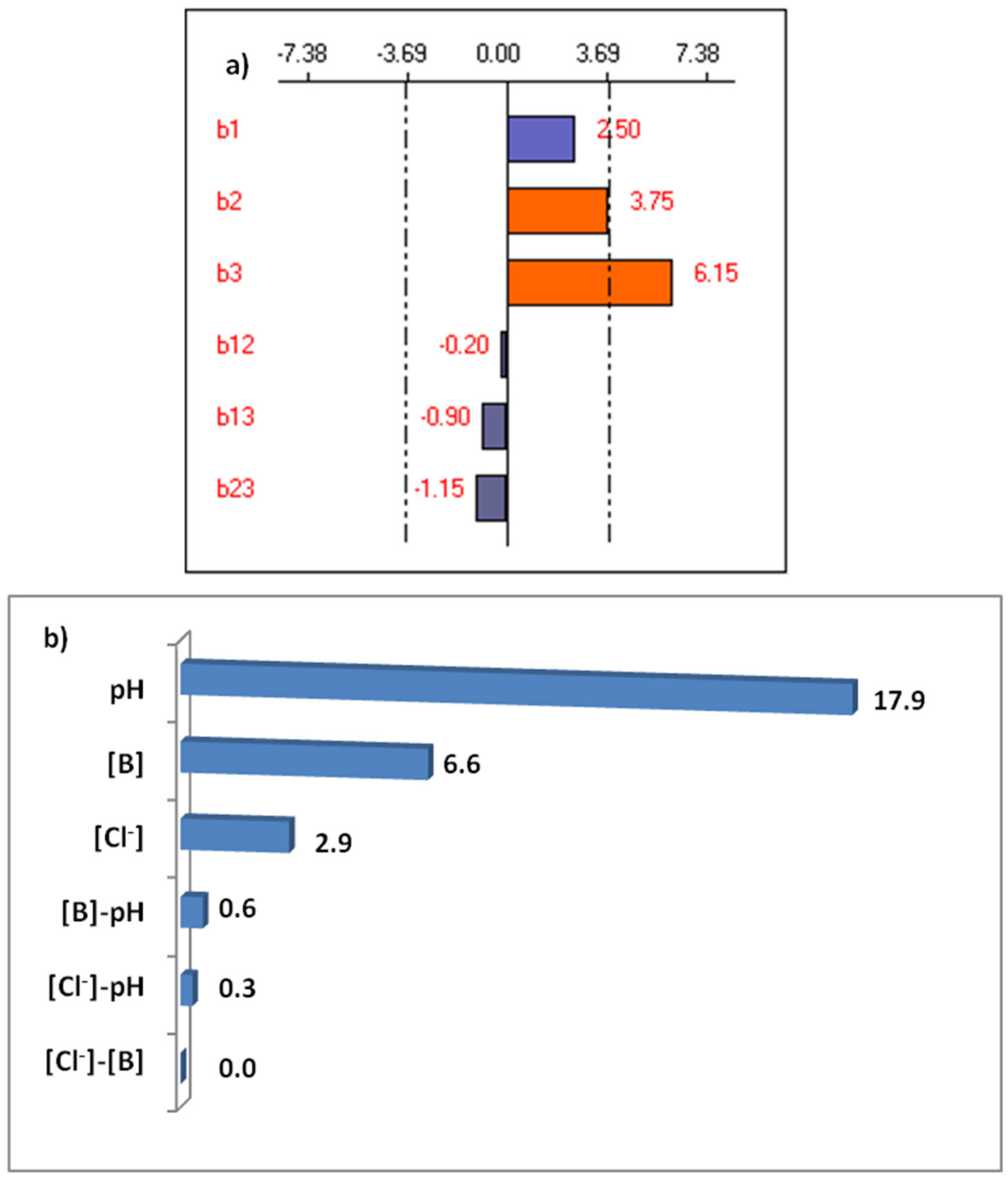

Figure 5. (a) Graphical analysis of the removal of boron, (b) Pareto effect.

The three studied parameters had a positive effect on the studied response, i.e., increasing them led to improvements in the boron removal. Their contributions to the studied response were only $6.6 \%$ for boron concentration and $2.9 \%$ for chloride concentration versus $17.9 \%$ for $\mathrm{pH}$. Thus, boron removal can be considerably influenced by two parameters: $\mathrm{pH}$ and boron concentration. The positive sign of the coefficient for the solution $\mathrm{pH}$ means 
that boron removal was improved. This is due to the presence of $\mathrm{B}(\mathrm{OH})_{4}^{-}$, which becomes the dominant species at high $\mathrm{pH}$ values. The counter-ion concentration and the boron concentration have moderately significant effects on the removal of boron by Donnan dialysis. Thus, the most important parameter is the $\mathrm{pH}$ of the feed compartment.

\subsection{Response Surface Methodology}

\subsubsection{Doehlert Design}

The response surface methodology (RSM) according to Doehlert design was performed in this study in order to determine the optimal condition. Doehlert's approach is formed by uniformly distributing the experimental points within the space filling the variables. The number of experiments for $\mathrm{k}$ factors is $\mathrm{N}=\mathrm{k}^{2}+\mathrm{k}+1$. A total number of 15 experiments including three replicates at the center field [24].

\subsubsection{Experimental Field}

The studied factors were the initial concentration of boron, the $\mathrm{pH}$ of the feed compartment and the concentration of counter-ions in the receiver compartment. The limits of these factors were fixed according to the preliminary study (Section 3.1). It is generally preferable to choose variables with important effects as the variable with maximum levels to obtain maximum information from the system. In Table 4, the experimental field of studied factors is presented.

Table 4. Experimental range and levels of the factors.

\begin{tabular}{|c|c|c|c|c|c|c|c|}
\hline Factors & \multicolumn{7}{|c|}{ Range and Levels } \\
\hline Coded Variable $X_{1}$ & \multirow{2}{*}{\multicolumn{2}{|c|}{$\begin{array}{l}-1 \\
0.1\end{array}$}} & -0.5 & \multirow{2}{*}{\multicolumn{2}{|c|}{$\begin{array}{c}0 \\
0.3\end{array}$}} & 0.5 & 1 \\
\hline Concentration of $\mathrm{Cl}^{-}(\mathrm{mol} / \mathrm{L})$ & & & 0.2 & & & 0.4 & 0.5 \\
\hline Coded Variable $\mathrm{X}_{2}$ & -0.866 & -0.577 & -0.287 & 0 & 0.287 & 0.577 & 0.866 \\
\hline $\mathrm{pH}$ & 10.6 & 10.9 & 11.2 & 11.5 & 11.8 & 12.1 & 12.4 \\
\hline Coded Variable $X_{3}$ & \multirow{2}{*}{\multicolumn{3}{|c|}{$\begin{array}{c}-0.816 \\
31\end{array}$}} & \multicolumn{2}{|c|}{0} & \multicolumn{2}{|c|}{0.816} \\
\hline Concentration of Boron $(\mathrm{mg} / \mathrm{L})$ & & & & \multicolumn{2}{|c|}{62} & \multicolumn{2}{|c|}{93} \\
\hline
\end{tabular}

\subsubsection{Modelling of Donnan Dialysis}

The Doehlert design is a matrix which makes it possible to estimate the coefficients of a second-order function, which is able to predict, at any point in the experimental domain, the values of the answer [24]. The chosen model describes the predicted values of the responses $\mathrm{Y}$ using a polynomial equation (Equation (5)).

$$
\mathrm{Y}=\mathrm{b}_{0}+\mathrm{b}_{1} \mathrm{X}_{1}+\mathrm{b}_{2} \mathrm{X}_{2}+\mathrm{b}_{3} \mathrm{X}_{3}+\mathrm{b}_{11} \mathrm{X}_{1}^{2}+\mathrm{b}_{22} \mathrm{X}_{2}^{2}+\mathrm{b}_{33} \mathrm{X}_{3}^{2}+\mathrm{b}_{12} \mathrm{X}_{1} \mathrm{X}_{2}+\mathrm{b}_{13} \mathrm{X}_{1} \mathrm{X}_{3}+\mathrm{b}_{23} \mathrm{X}_{2} \mathrm{X}_{3}
$$

The estimation of the principal effect of the factor $i$ are indicated as $b_{i}$, and the estimation of the second-order effects are indicated as $b_{i i}$; the estimation of the interactions between factor $i$ and factor $j$ are indicated as $b_{i j}$, and the coded variables are indicated as $X_{i}$.

\subsubsection{Validation of Models}

The validation of models were evaluated according to two criteria: the regression coefficient $\left(R^{2}\right)$ and the percentage absolute error of deviation (AED) between the experimental and calculated results. The AED was calculated from Equation (6):

$$
\operatorname{AED}(\%)=\frac{100}{\mathrm{~N}} \cdot\left|\frac{\mathrm{Y}_{\exp }-\mathrm{Y}_{\text {theo }}}{\mathrm{Y}_{\exp }}\right|
$$

where $Y_{\exp }$ and $Y_{\text {theo }}$ are the responses obtained from experiments and from the model, respectively. $\mathrm{N}$ is the number of points at which measurements were carried out. A model was considered valid if $R^{2}>0.7$ and AED $<10 \%$ [47]. 


\subsubsection{Optimization by Response Surface Methodology as Doehlert Design}

The objective is to simultaneously optimize the levels of these variables to attain the best system performance. In this study, response surface methodology via Doehlert design was employed with the AFN membrane to optimize the boron removal. A three-variable Doehlert experimental design involving 15 experiments, including 3 replicates at the center field (Table 5), was employed for factor optimization. We note the very small relative differences between the experimental and the calculated values.

Table 5. Doehlert matrix and the obtained results.

\begin{tabular}{|c|c|c|c|c|c|c|c|c|c|}
\hline $\mathbf{N}^{\circ}$ & $X_{1}$ & $X_{2}$ & $X_{3}$ & {$\left[\mathrm{Cl}^{-}\right]$} & $\mathrm{pH}$ & [B] & $Y(\%)_{\operatorname{Exp}}$ & $\mathrm{Y}(\%)_{\mathrm{Cal}}$ & Relative Difference (\%) \\
\hline 1 & 1.0 & 0.000 & 0.000 & 0.5 & 11.5 & 62 & 87.3 & 87.4 & 0.11 \\
\hline 2 & -1.0 & 0.000 & 0.000 & 0.1 & 11.5 & 62 & 81.5 & 81.4 & 0.12 \\
\hline 3 & 0.5 & 0.866 & 0.000 & 0.4 & 12.4 & 62 & 51.4 & 51.6 & 0.39 \\
\hline 4 & -0.5 & -0.866 & 0.000 & 0.2 & 10.6 & 62 & 16.1 & 15.9 & 1.25 \\
\hline 5 & 0.5 & -0.866 & 0.000 & 0.4 & 10.6 & 62 & 21.1 & 20.7 & 1.91 \\
\hline 6 & -0.5 & 0.866 & 0.000 & 0.2 & 12.4 & 62 & 50.7 & 50.6 & 0.19 \\
\hline 7 & 0.5 & 0.287 & 0.816 & 0.4 & 11.8 & 93 & 65.2 & 64.9 & 0.47 \\
\hline 8 & -0.5 & -0.287 & -0.816 & 0.2 & 11.2 & 31 & 35.9 & 36.2 & 0.83 \\
\hline 9 & 0.5 & -0.287 & -0.816 & 0.4 & 11.2 & 31 & 40.1 & 39.9 & 0.50 \\
\hline 10 & 0.0 & 0.577 & -0.816 & 0.3 & 12.1 & 31 & 46.6 & 46.5 & 0.21 \\
\hline 11 & -0.5 & 0.287 & 0.816 & 0.2 & 11.8 & 93 & 62.6 & 62.7 & 0.16 \\
\hline 12 & 0.0 & -0.577 & 0.816 & 0.3 & 10.9 & 93 & 39.5 & 39.6 & 0.25 \\
\hline 13 & 0.0 & 0.000 & 0.000 & 0.3 & 11.5 & 62 & 84.2 & 84.2 & 0.00 \\
\hline 14 & 0.0 & 0.000 & 0.000 & 0.3 & 11.5 & 62 & 84.2 & 84.2 & 0.00 \\
\hline 15 & 0.0 & 0.000 & 0.000 & 0.3 & 11.5 & 62 & 84.2 & 84.2 & 0.00 \\
\hline
\end{tabular}

Using the experimental results from Table 5, the second-order polynomial equation was fitted to the data appropriately, and the coefficients, $p$-values, $\mathrm{R}^{2}$ and AED are presented in Table 6.

Table 6. Model constants, $p$-values, $\mathrm{R}^{2}$ and AED values.

\begin{tabular}{|c|c|c|}
\hline & & $p$-Values \\
\hline $\mathrm{b}_{0}$ & 84.2 & 0.0001 \\
\hline$b_{1}$ & 3.01 & 0.0001 \\
\hline$b_{2}$ & 18.81 & 0.0001 \\
\hline$b_{3}$ & 9.12 & 0.0001 \\
\hline$b_{11}$ & 0.20 & 0.394 \\
\hline$b_{22}$ & -65.90 & 0.0001 \\
\hline$b_{33}$ & -37.40 & 0.0001 \\
\hline$b_{12}$ & -2.38 & 0.002 \\
\hline$b_{13}$ & -0.10 & 0.750 \\
\hline$b_{23}$ & -12.20 & 0.0001 \\
\hline $\mathrm{R}^{2}$ & \multicolumn{2}{|c|}{0.9999} \\
\hline $\operatorname{AED}(\%)$ & \multicolumn{2}{|c|}{0.425} \\
\hline
\end{tabular}


In Table 6, the coefficients are presented, which shows that the $\mathrm{pH}$ of the feed compartment had an important effect $\left(b_{2}=18.81\right)$ on the removal of boron. The second influencing factor was the boron concentration $\left(b_{3}=9.12\right)$. However, the concentration of chloride had a less important effect on the removal of boron $\left(b_{1}=3.01\right)$.

The most important interaction was between the $\mathrm{pH}$ of the feed compartment and boron concentration $\left(b_{23}=-12.20\right)$ which had a negative effect on the removal of boron by Donnan dialysis. However, the interaction between chloride concentration and $\mathrm{pH}$ of feed compartment $\left(b_{12}=-2.38\right)$ and the interaction concentration and boron concentration $\left(b_{13}=-0.10\right)$ were insignificant and had a negative effect on the removal of boron by Donnan dialysis.

The validation of the model was evaluated according to the regression coefficient $\left(\mathrm{R}^{2}\right)$ and the percentage of absolute errors of deviation (AED), and as indicated in Table 6, the regression coefficient $R^{2}=0.999$ was greater than 0.7 and the percentage absolute error of deviation AED $(\%)=0.425 \%$ was less than $10 \%$.

Analysis of variance (ANOVA) was performed. In this regard, the results are presented in Table 7. The $p$-value is defined as the ratio of the mean square effect, and the F-ratio is defined as the mean square error. For determining the effects which are statistically significant, the $p$-value has been used. The $p$-value is very important because it is near to zero; this indicates that the data are significant. According to the table of Fischer, for $5 \%$ of error, 1 degree of freedom and 15 factorial tests, the Fischer value was equal to 4.54 . It seems that all the effects were significant because all their value were higher than 4.54 . The Fischer value of the experimental model was much higher than the critical $F$ value at a level of $5 \%$. Therefore, the model is considered statistically significant. These confirm the model's validation and confirm that the model is suitable to describe boron removal.

Table 7. Analysis of variance.

\begin{tabular}{ccccccc}
\hline Source Model & Degrees of Freedom & Sum of Square & Mean of Square & F-Value & $\mathbf{F}_{\text {table }}(\boldsymbol{\alpha}=\mathbf{5 \%})$ & $\boldsymbol{p}$-Value \\
\hline Regression & 9 & 7988.2 & 887.6 & $88,758.7$ & 4.54 & 0.0001 \\
\hline Residual & 5 & 389.1 & 129.7 & & & \\
\hline Total & 14 & 8377.4 & & & & \\
\hline
\end{tabular}

In order to explain the removal of the boron by Donnan dialysis, the contour plots (curve of constant response) were used. These contour plots are a graphic analysis of iso-response curves at the chosen experimental field delimited by a circle, which confirmed the preceding results of the factorial design (Section 3.2). The obtained plots are provided in Figure 6.

Figure 6a shows the combined variation of chloride concentration and $\mathrm{pH}$ at a constant boron concentration of $62 \mathrm{mg} / \mathrm{L}$. The shape of the contour plots shows that only around $\mathrm{pH} 11.5$ did boron removal improve with an increasing chloride concentration from $0.1 \mathrm{mg} / \mathrm{L}$ to $0.3 \mathrm{mg} / \mathrm{L}$. This was attributed to the existing forms of boron in aqueous solution under different $\mathrm{pH}$ values. $\mathrm{B}(\mathrm{OH})_{4}^{-}$is the dominant species at higher $\mathrm{pH}$ values. However, above $\mathrm{pH} \mathrm{11.5,} \mathrm{the} \mathrm{transport} \mathrm{of} \mathrm{boron} \mathrm{is} \mathrm{probably} \mathrm{affected} \mathrm{by} \mathrm{the} \mathrm{presence} \mathrm{and}$ the competition with $\mathrm{OH}^{-}$, which decrease the removal of boron. Thus, it can be concluded that the highest boron transport was achieved at $\mathrm{pH} 11.5$. Figure $6 \mathrm{~b}$ presents the variation between the concentration of boron and $\mathrm{pH}$ at a constant chloride concentration of $0.3 \mathrm{~mol} / \mathrm{L}$. This result confirms that the $\mathrm{pH}$ greatly affects the removal of boron; this is reflected in the shape of these iso-response curves, which are concentrated in the center of the domain. This was expected because the $\mathrm{pH}$ and the chloride concentration were the factors which had a positive effect on the removal of boron. Figure $6 \mathrm{c}$ shows the variation in chloride concentration and boron concentration at a constant $\mathrm{pH}$ of 11.5. The shape of the contour plots show that only around a boron concentration of $62 \mathrm{mg} / \mathrm{L}$ did its removal improve when increasing the chloride concentration from $0.1 \mathrm{mg} / \mathrm{L}$ to $0.3 \mathrm{mg} / \mathrm{L}$. 

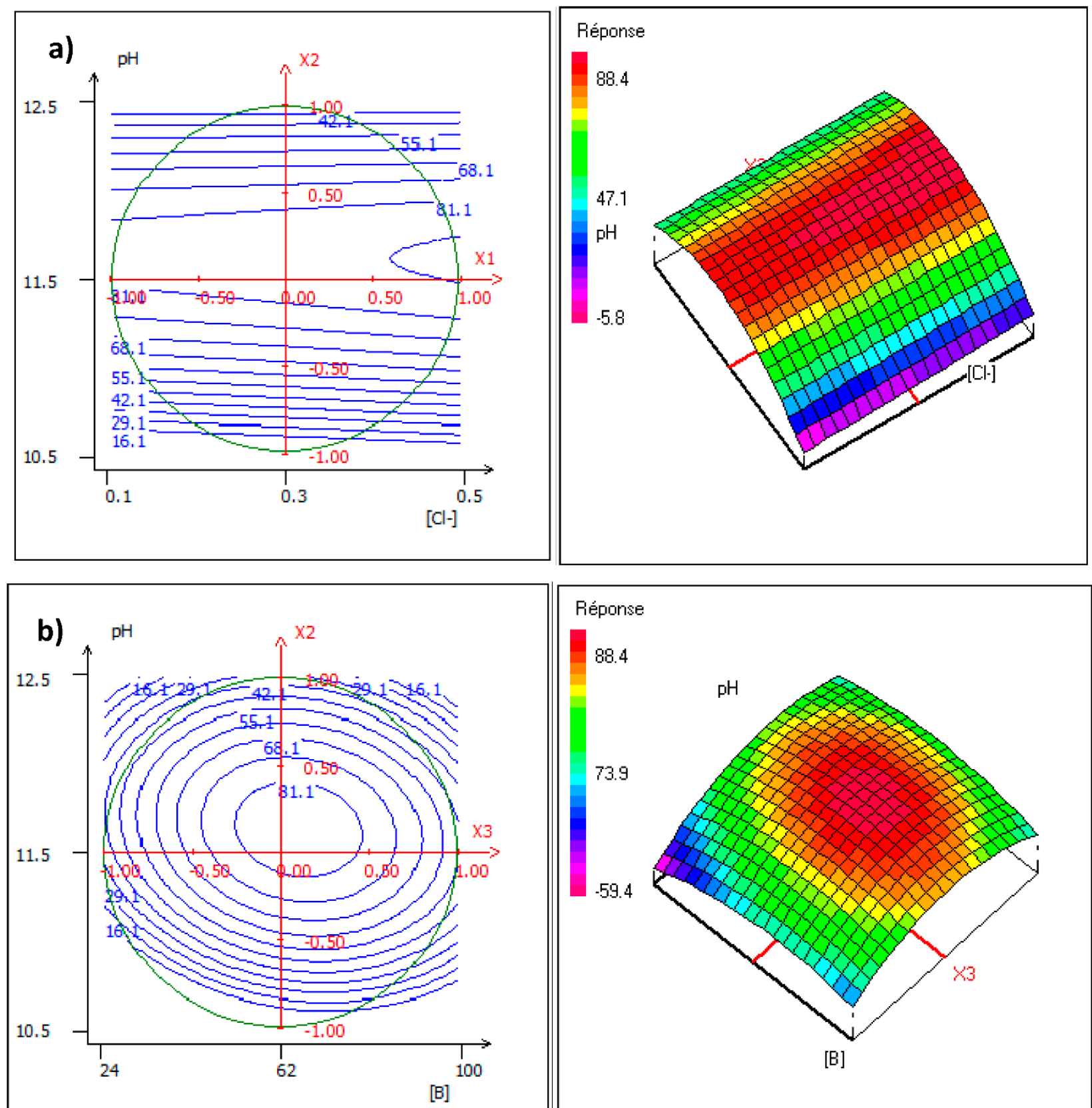

Figure 6. Cont. 



Figure 6. Contour plots and three-dimensional plots of (a) chloride concentration versus $\mathrm{pH}$, (b) of boron concentration versus $\mathrm{pH},(\mathbf{c})$ chloride concentration versus boron concentration.

In the software NEMRODW ${ }^{\circledR}$, a function named "desirability" provided the optimum value. Therefore, the optimum values were $66 \mathrm{mg} / \mathrm{L}$ for the concentration of boron, $0.5 \mathrm{~mol} / \mathrm{L}$ for the concentration of chloride, and 11.6 for the $\mathrm{pH}$ of the feed compartment. These conditions led to a maximum boron removal of $88.8 \%$. Three replicates of the experiment were conducted in the optimum conditions, in order to verify the efficiency of the predicted values. The coefficients of repeatability and of reproducibility were less than $1 \%$ and $5 \%$, respectively; therefore, it can be concluded that the removal of boron by Donnan dialysis is reproducible.

Table 8 presents a comparison with previous studies of the removal of boron by Donnan dialysis. It can be concluded that the use of response surface methodology can be considered a good solution to determine the optimum conditions.

Table 8. Comparative studies of boron removal by Donnan dialysis.

\begin{tabular}{|c|c|c|}
\hline Reference & $\begin{array}{l}\text { Composition of Feed and } \\
\text { Receiver Compartment }\end{array}$ & Efficiency for Boron Removal (\%) \\
\hline$[40]$ & $\begin{array}{c}\text { Feed: } 0.1 \mathrm{~mol} / \mathrm{L} \text { of } \mathrm{B} \\
\mathrm{pH}=9.5 \\
\text { Receiver: } 0.1 \mathrm{~mol} / \mathrm{L} \text { of } \mathrm{Cl}^{-}\end{array}$ & $\begin{array}{l}0.1 \% \text { removal with AHA membrane } \\
0.1 \% \text { removal with AMH membrane } \\
0.5 \% \text { removal with AFN membrane }\end{array}$ \\
\hline [18] & $\begin{array}{c}\text { Feed: } 75 \mathrm{mg} / \mathrm{L} \text { of } \mathrm{B} \\
\mathrm{pH}=11.1 \\
\text { Receiver: } 1.0 \mathrm{~mol} / \mathrm{L} \text { of } \mathrm{OH}^{-}\end{array}$ & $0.8 \%$ removal with AMX membrane \\
\hline [19] & $\begin{array}{c}\text { Feed: } 20 \mathrm{mg} / \mathrm{L} \text { of } \mathrm{B} \\
\mathrm{pH}=9.5 \\
\text { Receiver: } 1 \mathrm{~mol} / \mathrm{L} \text { of } \mathrm{Cl}^{-}\end{array}$ & $\begin{array}{l}30 \% \text { removal by PEI }-2 \text { membrane } \\
40 \% \text { removal by PEI- } 3 \text { membrane }\end{array}$ \\
\hline Our work & $\begin{array}{c}\text { Feed: } 66 \mathrm{mg} / \mathrm{L} \text { of } \mathrm{B} \\
\mathrm{pH}=11.5 \\
\text { Receiver: } 0.5 \mathrm{~mol} / \mathrm{L} \text { of } \mathrm{Cl}^{-}\end{array}$ & $88.8 \%$ removal by AFN membrane \\
\hline
\end{tabular}




\section{Conclusions}

The removal of boron by Donnan dialysis was performed with two membranes, AFN and ACS, according to different parameters such as the $\mathrm{pH}$ value of the feed compartment, the concentration of counter-ions in the receiver compartment, and the concentration of boron in the feed compartment. The removal of boron by Donnan dialysis reached $75 \%$ and $48 \%$ with AFN and ACS membranes, respectively; the solution of boron had an initial

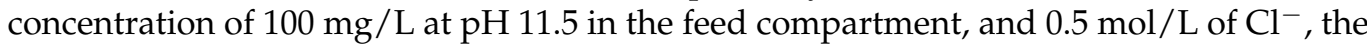
counter-ion, in the receiver compartment. A full factorial design was conducted in order to study the influence and the interaction of parameters; thus, it was concluded that the $\mathrm{pH}$ is the most important parameter for the removal of boron. The response surface methodology via Doehlert enabled establishment of the optimal working conditions for the removal of boron reaching $88.8 \%$ with the AFN membrane, which were: $[\mathrm{B}]=66 \mathrm{mg} / \mathrm{L}, \mathrm{pH}=11.6$ and $\left[\mathrm{Cl}^{-}\right]=0.5 \mathrm{~mol} / \mathrm{L}$. The use of response surface methodology could be considered a good solution to determine the optimum conditions for $13.8 \%$ removal compared to the traditional "one-at-a-time" technique.

Author Contributions: Conceptualization, I.M.T.; Methodology, I.M.T. and L.C., Statistical and formal analysis, I.M.T. and L.B., Writing-original draft preparation, I.M.T., L.C and L.D.; writingreview and editing, I.M.T., L.B., L.D. and B.H. All authors have read and agreed to the published version of the manuscript.

Funding: This research received no external funding.

Institutional Review Board Statement: Not applicable.

Informed Consent Statement: Not applicable.

Data Availability Statement: Not applicable.

Acknowledgments: The authors thank all who assisted in contributing to this work.

Conflicts of Interest: The authors declare no conflict of interest.

\section{References}

1. Brdar-Jokanovic, M. Boron Toxicity and Deficiency in Agricultural Plants. Int. J. Mol. Sci. 2020, 21, 1424. [CrossRef] [PubMed]

2. Pandey, A.; Khan, M.K.; Hakki, E.E.; Gezgin, S.; Hamurcu, M. Combined Boron Toxicity and Salinity Stress-An Insight into Its Interaction in Plants. Plants 2019, 8, 364. [CrossRef] [PubMed]

3. Guler, E.; Kaya, C.; Kabay, N.; Arda, M. Boron removal from seawater: State of the art review. Desalination 2015, 356, 85-93. [CrossRef]

4. Chruszcz-Lipska, K.; Winid, B.; Madalska, G.A.; Macuda, J.; Lukanko, L. High Content of Boron in Curative Water: From the Spa to Industrial Recovery of Borates? (Poland as a Case Study). Minerals 2021, 11, 8. [CrossRef]

5. Lyu, J.; Zhang, N.; Liu, H.; Zeng, Z.; Zhang, J.; Bai, P.; Guo, X. Adsorptive removal of boron by zeolitic imidazolate framework: Kinetics, isotherms, thermodynamics, mechanism and recycling. Sep. Purif. Technol. 2017, 187, 67-75. [CrossRef]

6. Ting, T.M.; Nasef, M.M.; Aravindan, D.; Rosslan, I.F.N.; Ruslan, N. Selective removal of boron from industrial wastewater containing high concentration of ammonia by radiation grafted fibrous adsorbent in fixed bed column. J. Environ. Chem. Eng. 2021, 9, 104993. [CrossRef]

7. Yilmaz, A.; Boncukcuoğlu, R.; Kocakerim, M. A quantitative comparison between electrocoagulation and chemical coagulation for boron removal from boron-containing solution. J. Hazard. Mater. 2007, 149, 475-481. [CrossRef]

8. Chen, M.; Dollar, O.; Shafer-Peltier, K.; Randtke, S.; Waseem, S.; Peltier, E. Boron removal by electrocoagulation: Removal mechanism, adsorption models and factors influencing removal. Water Res. 2020, 170, 115362. [CrossRef]

9. Turek, M.; Dydo, P.; Bandura-Zalska, B. Boron removal from dual-staged seawater nanofiltration permeate by electrodialysis. Desalin. Water Treat. 2009, 10, 60-63. [CrossRef]

10. Guesmi, F.; Louati, I.; Hannachi, C.; Hamrouni, B. Optimization of boron removal from water by electrodialysis using response surface methodology. Water Sci. Technol. 2020, 81, 293-300. [CrossRef]

11. Ali, Z.; Al Sunbul, Y.; Pacheco, F.; Ogieglo, W.; Wang, Y.; Genduso, G.; Pinnau, I. Defect-free highly selective polyamide thin-film composite membranes for desalination and boron removal. J. Membr. Sci. 2019, 578, 85-94. [CrossRef]

12. Li, Y.; Wang, S.; Song, X.; Zhou, Y.; Shen, H.; Cao, X.; Zhang, P.; Gao, C. High boron removal polyamide reverse osmosis membranes by swelling induced embedding of a sulfonyl molecular plug. J. Membr. Sci. 2020, 597, 117716. [CrossRef] 
13. Kumar, R.; Ahmed, M.; Ok, S.; Garudachari, B.; Thomas, J.P. Boron selective thin film composite nanofiltration membrane fabricated via a self-assembled trimesic acid layer at a liquid-liquid interface on an ultrafiltration support. New J. Chem. 2019, 43, 3874-3883. [CrossRef]

14. Lan, N.; Wang, K.Y.; Weber, M.; Maletzko, C.; Chung, T.S. Investigation of novel molecularly tunable thin-film nanocomposite nanofiltration hollow fiber membranes for boron removal. J. Membr. Sci. 2021, 620, 118887. [CrossRef]

15. Alharati, A.; Swesi, Y.; Fiaty, K.; Charcosset, C. Boron removal in water using a hybrid membrane process of ion exchange resin and microfiltration without continuous resin addition. J. Water Process. Eng. 2017, 17, 32-39. [CrossRef]

16. Hussain, A.; Sharma, R.; Minier-Matar, J.; Hirani, Z.; Adhama, S. Application of emerging ion exchange resin for boron removal from saline groundwater. J. Water Process. Eng. 2019, 32, 100906-100915. [CrossRef]

17. Eryildiz, B.; Yuksekdag, A.; Korkut, S.; Koyuncu, İ. Performance evaluation of boron removal from wastewater containing high boron content according to operating parameters by air gap membrane distillation. Environ. Technol. Innov. 2021, $22,101493$. [CrossRef]

18. Turek, M.; Bandura-Zalska, B.; Dydo, P. Boron removal by Donnan dialysis. Desalin. Water Treat. 2009, 10, 53-59. [CrossRef]

19. Bryjak, M.; Duraj, I. Anion-exchange membranes for separation of borates by Donnan dialysis. Desalination 2013, 310, 39-42. [CrossRef]

20. DiNunzio, J.E.; Jubara, M. Donnan Dialysis Preconcentration for Ion Chromatography. Anal. Chem. 1983, 55, 1013-1016. [CrossRef]

21. Sato, K. Effects of the feed solution concentration on the separation degree in Donnan dialysis for binary systems of amino acids. J. Membr. Sci. 2002, 196, 211-220. [CrossRef]

22. Seneviratne, J.; Holmstrom, S.D.; Cox, J.A. Donnan Dialysis Preconcentration Coupled with Ion Chromatography and Electrocatalytic Oxidation for the Determination of Cyanide. Talanta 2000, 52, 1025-1031. [CrossRef]

23. Ben Hamouda, S.; Touati, K.; Ben Amor, M. Donnan dialysis as membrane process for nitrate removal from drinking water: Membrane structure effect. Arab. J. Chem. 2017, 10, S287-S292. [CrossRef]

24. Marzouk Trifi, I.; Trifi, B.; Djamel, A.; Hamrouni, B. Simultaneous removal of nitrate and nitrite by Donnan Dialysis. Environ. Eng. Manag. J. 2020, 20, 973-983.

25. Dieye, A.; Larchet, C.; Auclair, B.; Mar-Diop, C. Elimination des fluorures par la dialyse ionique croisée. Eur. Polym. J. 1998, 34, 67-75. [CrossRef]

26. Hichour, M.; Persin, F.; Sandeaux, J.; Gavach, C. Fluoride removal from waters by Donnan dialysis. Sep. Purif. Technol. 2000, 18, 1-11. [CrossRef]

27. Hichour, M.; Persin, F.; Molenat, J.; Sandeaux, J.; Gavach, C. Fluoride removal from diluted solutions by donnan dialysis with anion exchange membranes. Desalination 1999, 122, 53-62. [CrossRef]

28. Marzouk, I.; Dammak, L.; Chaabane, L.; Hamrouni, B. Optimization of chromium (VI) removal by Donnan dialysis. Am. J. Anal. Chem. 2013, 4, 306-313. [CrossRef]

29. Marzouk, I.; Chaabane, L.; Dammak, L.; Hamrouni, B. Application of Donnan dialysis coupled to adsorption onto activated alumina for chromium (VI) removal. Am. J. Anal. Chem. 2013, 4, 420-425. [CrossRef]

30. Marzouk Trifi, I.; Trifi, B.; Ben Ayed, S.; Hamrouni, B. Removal of phosphate by Donnan dialysis coupled to adsorption onto alginate calcium beads. Water Sci. Technol. 2019, 80, 117-125. [CrossRef] [PubMed]

31. Rangaiah, G.P.; Feng, Z.; Hoadley, A.F. Multi-Objective Optimization Applications in Chemical Process Engineering: Tutorial and Review. Processes 2020, 8, 508. [CrossRef]

32. French Standard NF X 45-200, Membranes Polymers Échangeuse d'Ions; AFNOR: Paris, France, 1995.

33. Strathmann, H. Ion-Exchange Membrane Separation Processes, 1st ed.; Elsevier Science: Amsterdam, The Netherlands, 2004.

34. Nouri, S.; Dammak, L.; Bulvestre, G.; Auclair, B. Studies of the crossed ionic fluxes through a cation-exchange membrane in the case of Donnan dialysis. Desalination 2002, 148, 383-388. [CrossRef]

35. Mokrani, S.; Dammak, L.; Bulvestre, G.; Auclair, B. Experimental and theoretical studies of the crossed ionic fluxes through a cation-exchange membrane. J. Membr. Sci. 2002, 199, 147-160. [CrossRef]

36. Wisniewski, J.; Rozanska, A. Donnan dialysis with anion exchange membranes as a pretreatment step before electrodialytic desalination. Desalination 2006, 191, 210-218. [CrossRef]

37. Rozanska, A.; Wiśniewski, J.; Winnicki, T. Donnan dialysis with anion-exchange membranes in a water desalination system. Desalination 2006, 198, 236-246. [CrossRef]

38. Rodier, J. L'analyse de l'eau, 9th ed.; Edition Dunod: Paris, France, 2009.

39. Zohdi, N.; Mahdavi, F.; Abdullah, L.C.; Choong, T.S.Y. Removal of boron from aqueous solution using magnetic carbon nanotube improved with tartaric acid. J. Environ. Health Sci. Eng. 2014, 12, 3-15. [CrossRef] [PubMed]

40. Ayyildiz, H.F.; Kara, H. Boron removal by ion exchange membranes. Desalination 2005, 180, 99-108. [CrossRef]

41. Veerman, J. The Effect of the $\mathrm{NaCl}$ Bulk Concentration on the Resistance of Ion Exchange Membranes-Measuring and Modeling. Energies 2020, 13, 1946. [CrossRef]

42. Amang, D.N.; Alexandrova, S.; Schaetzel, P. Mass transfer characterization of Donnan dialysis in a bi-ionic chloride-nitrate system. Chem. Eng. J. 2004, 99, 69-76. [CrossRef]

43. Wisniewski, J.; Rozanska, A.; Winnicki, T. Removal of troublesome anions from water by means of Donnan dialysis. Desalination 2005, 182, 339-346. [CrossRef] 
44. Tor, A.; Çengeloğlu, Y.; Ersöz, M.; Arslan, G. Transport of chromium through cation-exchange membranes by Donnan dialysis in the presence of some metals of different valences. Desalination 2004, 170, 151-159. [CrossRef]

45. Akretche, D.; Kerdjoudj, H. Donnan dialysis of copper, gold and silver cyanides with various anion exchange membranes. Talanta 2000, 51, 281-289. [CrossRef]

46. Hosni, N.; Zehani, K.; Djebali, K.; Mazaleyrat, F.; Bessais, L.; Maghraoui-Meherzi, H. Experimental design approach for the synthesis of 3D-CoFe ${ }_{2} \mathrm{O}_{4}$ nanoflowers thin films by low-cost process. Mater. Chem. Phys. 2020, 255, 123493-123503. [CrossRef]

47. Nde Bup, D.; Abi, C.F.; Tenin, D.; Kapseu, C.; Tchiegang, C. Optimisation of the cooking process of sheanut kernels (vitellaria paradoxa gaertn.) using the Doehlert experimental design. Food. Bioproc. Technol. 2012, 5, 108-117. [CrossRef] 